\title{
維持透析患者における赤血球内アルミニウム $(\mathrm{RBC}-\mathrm{Al})$ 濃度と 鉄パラメータについて
}

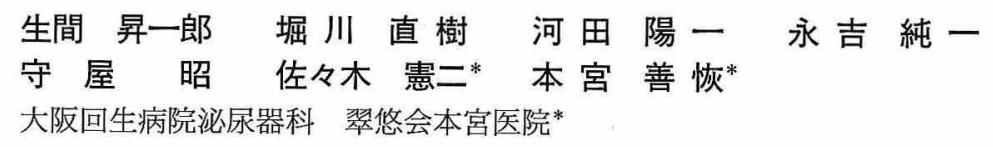

key words: RBC-aluminum, anemia, hemodialysis patient

〈要旨〉

維持透析患者におけるアルミニウム賓血症は，発症機序の一つとして鉄代謝障害が考えられている，今回我々は維 持透析患者 25 人を対象として, アルミニウム蓄積の鉄代謝への影響を検討するために, RBC-Al 濃度と鉄代謝パラ メータの比較を行った。

鉄代謝パラメータとして, 血清 $\mathrm{Fe}$, トランスフェリン (Tf), TIBC, UIBC, 血清フェリチン (Ft) 值を測定した。

RBC-Al 濃度は, 健常者 $31.9 \pm 9.9 \mu \mathrm{g} / 10^{13}$ cells に対し, 維持透析患者 $66.5 \pm 33.6 \mu \mathrm{g} / 10^{13} \mathrm{cells}$ と透析患者群で 有意に高值を示した. RBC-Al 濃度と Hb との間には相関は認めなかった. $\mathrm{Fe} / \mathrm{Tf}$ とはR=-0.515, Fe/TIBC とは $\mathrm{R}=-0.505$ の負の相関を認めた.

以上より，臨床的にもアルミニウムの蓄積が鉄代謝障害を介して，賓血症の発生に関与している可能性が示唆され た.

\section{Red blood cell aluminum (RBC-Al) content and iron parameters in mainte- nance hemodialysis patients}

Shoichiro Ikuma, Naoki Horikawa, Yoichi Kawata, Junichi Nagayoshi, Akira Moriya, Kenji Sasaki*, Yoshihiro Motomiya*

Department of Urology, Osaka Kaisei Hospital ; Suiyukai Motomiya Clinic*

To investigate the role of aluminum (Al) in the anemia of hemodialysis patients, we measured the red blood cell Al content (RBC-Al) of 25 hemodialysis patients by Yamada's method and compared it with various iron parameters. RBC-Al concentration was $31.9 \pm 9.9 \mu \mathrm{g} / 10^{13}$ cells in normal subjects $(n=7)$ and increased as high as $66.5 \pm 33.6 \mu \mathrm{g} / 10^{13}$ cells in hemodialysis patients. Although no correlation could be found between RBC-Al and hemoglobin concentration, a significant negative correlation was detected between RBC-Al content and both $\mathrm{Fe} /$ Tf $(R=-0.515, p<0.01)$ and Fe/TIBC $(R=-0.505, p<0.01)$. This suggests that the accumulation of $A$ l may interfere with Fe metabolism, especially its transport by transferrin, and result in the development of anemia in hemodialysis patients.

\section{緒言}

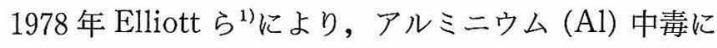
起因する維持透析患者における小球性低色素性貿血が指 摘されて以来, $\mathrm{Al}$ 蓄積が腎性貧血症の一因として注目さ れ, その発症機序の一つに鉄代謝障害が考元られている。 今回, 我々は赤血球アルミニウム $(\mathrm{RBC}-\mathrm{Al})$ 濃度を測定
し, 血清 $\mathrm{Fe}, \mathrm{TIBC}$, トランスフェリン (Tf), フェリチ

ン (Ft) 值などの鉄代謝パラメータとの比較検討を行っ たので報告する。

\section{対象と方法}

1. 対象は安定した維持透析患者 25 例, 年齢 29〜63 歳 で, 原疾患は全例非糖尿病性腎疾患であった。透析歷は 
16〜153 か月である（表 1).

2. 透析方法は全例フォローファイバー型ダイアライ ザーを使用し， RO 処理水を用いたバイカーボネート透 析である。

3. 血清 $\mathrm{Al}$ は従来通り, 原子吸光法により測定した.

4. RBC-Al は, 山田の方法 ${ }^{2,3}$ に準じて測定し, 赤血 球 $10^{13}$ 個当りに換算して值を求めた.

\section{結果}

1. 血液生化学検查成績：関連血液検査値は, $\mathrm{Hb} 7.9 \pm$ $1.5 \mathrm{~g} / \mathrm{d} l$, 血清 Fe $69.5 \pm 19.7 \mu \mathrm{g} / \mathrm{d}$ l, 血清 $\mathrm{Al} 74.4 \pm 34.1$ $\mu \mathrm{g} / l$ であった(表 2 ).

2. $\mathrm{RBC}-\mathrm{Al}$ 濃度： 7 人の健常者では, 22.3〜 $52.1 \mu \mathrm{g} /$ $10^{13}$ cells, 平均 $31.9 \pm 9.9 \mu \mathrm{g} / 10^{13}$ cells であった。一方, 維持透析患者では, $27.7 \sim 143.9 \mu \mathrm{g} / 10^{13}$ cells, 平均 66.5 $\pm 33.6 \mu \mathrm{g} / 10^{13}$ cells と有意に高值を認めた。ささらに, 25 例中 4 例に $100 \mu \mathrm{g} / 10^{13}$ cells 以上の異常高值が測定さ れ, 一方 $50 \mu \mathrm{g} / 10^{13}$ cells 以下の正常範囲内の症例は 25 例中 10 例であった（図 1).

3. $\mathrm{RBC}-\mathrm{Al}$ 濃度と血清 $\mathrm{A} 1$ 值 : $\mathrm{RBC}-\mathrm{Al}$ 濃度と血清 $\mathrm{Al}$ 值の間には，有意な相関は認められなかった(図 2).

4. $\mathrm{RBC}-\mathrm{Al}$ 濃度と $\mathrm{Hb}$ 值 : $\mathrm{RBC}-\mathrm{Al}$ 濃度と $\mathrm{Hb}$ 值と. も今回は相関は認められなかった（図 3 ).

5. RBC-Al 濃度扔よび血清 $\mathrm{Al}$ 值と血清 $\mathrm{Fe}$ 值: $\mathrm{RBC}-\mathrm{Al}$ 濃度と血清 $\mathrm{Fe}$ の間には， $\mathrm{R}=-0.586$ の負の 相関は認められたが, 血清 $\mathrm{Al}$ と血清 $\mathrm{Fe}$ の間には, 相 関は認められなかった（図 4,5)。

6. RBC-Al 濃度抢よび血清 $\mathrm{Al}$ 值と $\mathrm{Fe} / \mathrm{Tf}: \mathrm{RBC}-$ $\mathrm{Al}$ 濃度と $\mathrm{Fe} / \mathrm{Tf}$ の間には, $\mathrm{R}=-0.515$ の負の相関は 認められ， RBC-Al<50 $\mu \mathrm{g} / 10^{13} \mathrm{cells}$ の正常範囲内の症 例 11 例中 8 例に 0.3 以上の $\mathrm{Fe} / \mathrm{Tf}$ 值が認められたのに 対し, RBC- $\mathrm{Al}>50 \mu \mathrm{g} / 10^{13}$ cells の症例 14 例中 5 例に しか 0.3 以上の $\mathrm{Fe} / \mathrm{Tf}$ 值が認められなかった。一方，血 清 $\mathrm{Al}$ と $\mathrm{Fe} / \mathrm{Tf}$ の間には，相関は認められなかった（図 $6,7)$.

7. RBC-Al 濃度抢よび血清 $\mathrm{Al}$ 值と $\mathrm{Fe} / \mathrm{TIBC}$ : $\mathrm{RBC}-\mathrm{Al}$ 濃度と $\mathrm{Fe} / \mathrm{TIBC}$ の間には, $\mathrm{R}=-0.505$ の負 の相関は認められたが，血清 $\mathrm{Al}$ と $\mathrm{Fe} / \mathrm{TIBC}$ の間には， 相関は認められなかった（図 8，9）.

8. RBC-Al 濃度と鉄欠泛状態：血清Ft 值 $50 \mathrm{ng} / \mathrm{m} l$ を境界值として非鉄欠乏例と鉄欠乏例に分けて，そ机ぞ れの $\mathrm{RBC}-\mathrm{Al}$ 濃度を比較した結果, 鉄欠乏群で図 10 の ごとく, RBC-Al 高值がみられ，しかも $100 \mu \mathrm{g} / 10^{13} \mathrm{cells}$ 以上の異常高值が 4 例も認められた。

\section{考察}

古くは，Kehoe ら出により正常人では全血中の Al は， 大部分が血漿中にあり, 赤血球内にはほとんど認められ
表 1 Patient profile

\begin{tabular}{l|l}
\hline Number & 25 \\
\hline Sex & male 10 female 15 \\
\hline Age (yo) & $29 \sim 63 \quad(49.0 \pm 12.3)$ \\
\hline $\begin{array}{c}\text { Primary } \\
\text { disease }\end{array}$ & non-diabetic renal disedse \\
\hline $\begin{array}{c}\text { HD duration } \\
\text { (months) }\end{array}$ & $18 \sim 153(55.9 \pm 38.7)$ \\
\hline
\end{tabular}

表 2 Laboratory data

\begin{tabular}{llc}
\hline $\mathrm{RBC}$ & $\left(/ \mathrm{mm}^{3}\right)$ & $258.3 \pm 49.7 \times 10^{4}$ \\
$\mathrm{Hb}$ & $(\mathrm{g} / \mathrm{d} l)$ & $7.9 \pm 1.5$ \\
$\mathrm{MCV}$ & $\left(\mu^{3}\right)$ & $96.3 \pm 5.8$ \\
$\mathrm{Fe}$ & $(\mu \mathrm{g} / \mathrm{d} l)$ & $69.5 \pm 19.7$ \\
$\mathrm{TIBC}$ & $(\mu \mathrm{g} / \mathrm{d} l)$ & $263.4 \pm 46.1$ \\
$\mathrm{Tf}$ & $(\mathrm{mg} / \mathrm{d} l)$ & $242.3 \pm 35.8$ \\
Ferritin & $(\mathrm{ng} / \mathrm{m} l)$ & $70.9 \pm 90.7$ \\
$\mathrm{Al}$ & $(\mu \mathrm{g} / l)$ & $74.4 \pm 34.1$ \\
\hline
\end{tabular}

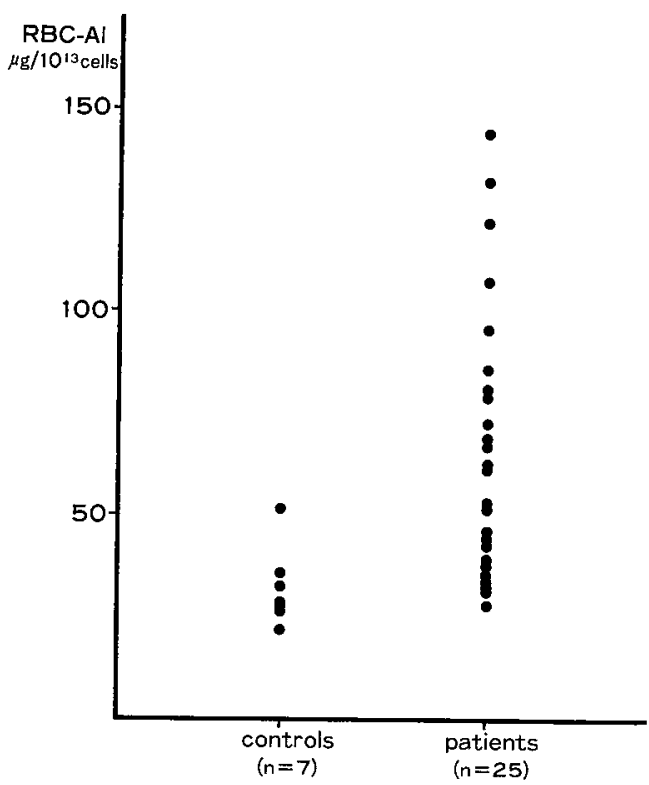

図 1 RBC-Al in controls and hemodialysis patients

ないと報告されていたが, 今回の測定での $\mathrm{RBC}-\mathrm{Al}$ と血 清 $\mathrm{Al}$ の比較では, 正常者の $\mathrm{RBC}-\mathrm{Al}$ 值 $(31.9 \pm 9.9 \mu \mathrm{g}$ / $10^{13}$ cells $)$ は正常血清 $\mathrm{Al}$ 值 $(5 \mu \mathrm{g} / l$ 以下 $)$ より著しく高 值（赤血球の $\mathrm{MCV}=100 \times 10^{-15} l=10^{-13} l$ として, $\mathrm{RBC} 10^{13}$ 個の容積は $1 l$ に相当する) であり, 菊池ら ${ }^{5)}$, 梅田 ${ }^{6)}$, Van der Voet $ら^{7)}$, Molitaris ${ }^{8)} も$ 同様の結果 を報告している。ささら，Tf-receptor は erythroblast に存在するが, 成熟した erythrocyte には存在しない早と 


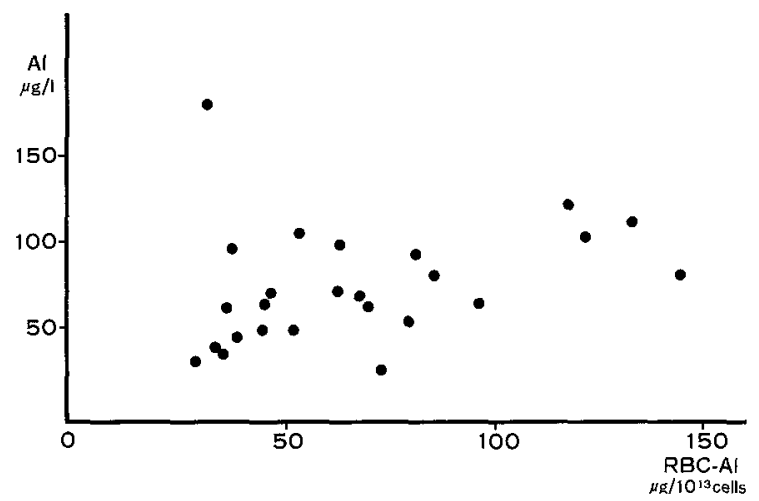

図 2 Relationship between $\mathrm{Al}$ and $\mathrm{RBC}-\mathrm{Al}$ in hemodialysis patients

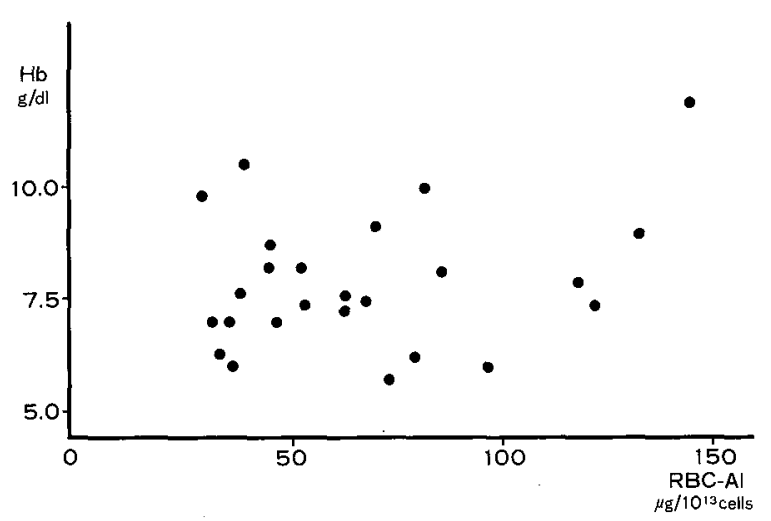

図 3 Relationship between $\mathrm{Hb}$ and $\mathrm{RBC}-\mathrm{Al}$ in hemodialysis patients

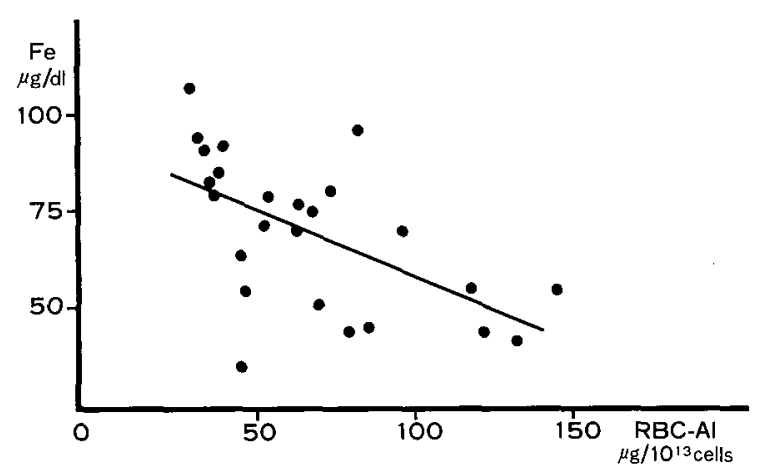

図 4 Relationship between $\mathrm{Fe}$ and $\mathrm{RBC}-\mathrm{Al}$ in hemodialysis patients

考えられて抢り, 従って, RBC-Al は末梢循環中で passive に血漿 $\mathrm{Al}$ が移動したものではなく, bone marrow 中での赤血球成熟過程で Tf-receptor なへして細胞内 に入った $\mathrm{Al}$ をほぼ反映していると解釈できる。つまり， $\mathrm{RBC}-\mathrm{Al}$ は bone marrow の $\mathrm{Al}$ 蓄積を反映しているこ

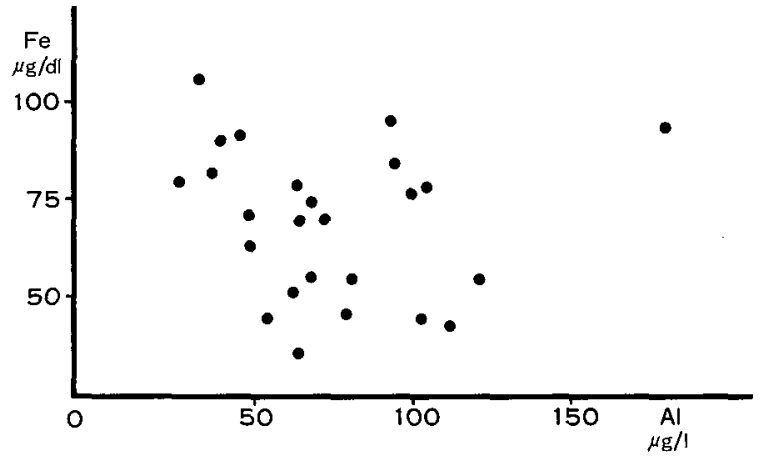

図 5 Relationship between $\mathrm{Fe}$ and $\mathrm{Al}$ in hemodialysis patients

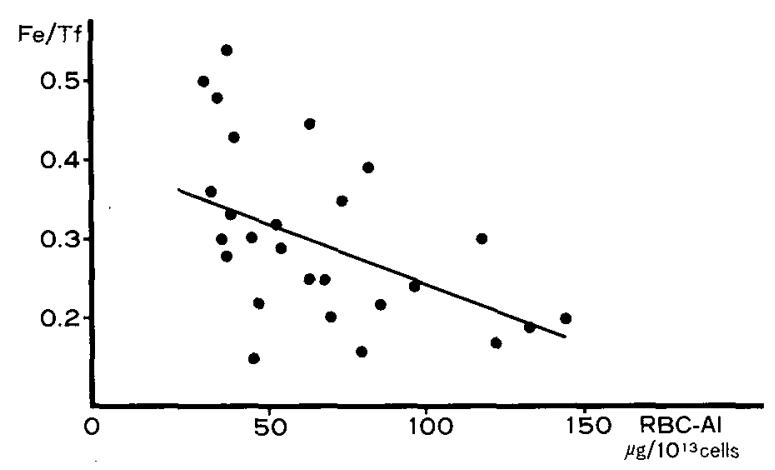

図 6 Relationship between $\mathrm{Fe} / \mathrm{Tf}$ and $\mathrm{RBC}$ $\mathrm{Al}$ in hemodialysis patients

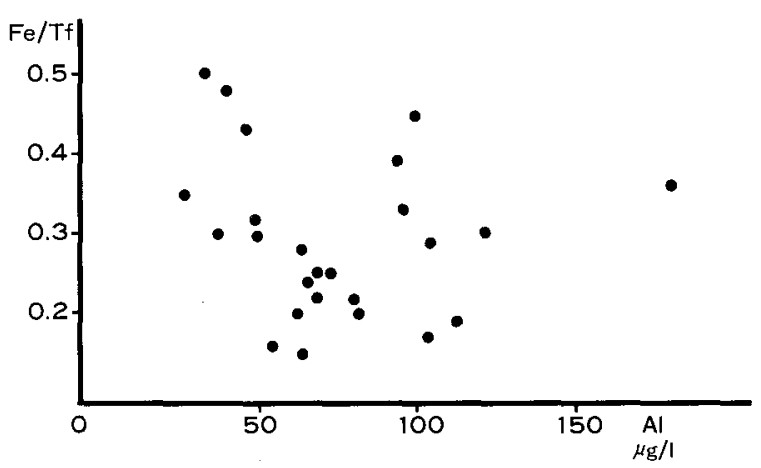

図 7 Relationship between $\mathrm{Fe} / \mathrm{Tf}$ and $\mathrm{Al}$ in hemodialysis patients

とになり，ひいては体内の $\mathrm{A} 1$ 蓄積濃度をあらわしてい ると考えられる。

維持透析患者における Al 貧血症の発生機序は，1） 赤血球分化過程での障害 ${ }^{10)} ， 2$ ）へム合成系酵素への障 害 $^{11213)}$ ，および今回テーマとした 3) 鉄代謝障害の $3 つ$ が想定される. 鉄代謝障害は，1）貯蔵鉄の Tfへの移 行, 2 ) Tf と鉄との結合の 2 つの過程での障害が考えら 


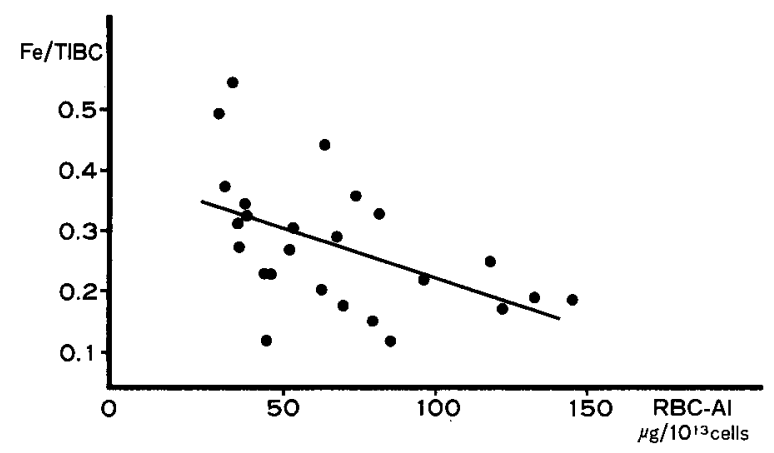

図 8 Relationship between $\mathrm{Fe} / \mathrm{TIBC}$ and RBC$\mathrm{Al}$ in hemodialysis patients

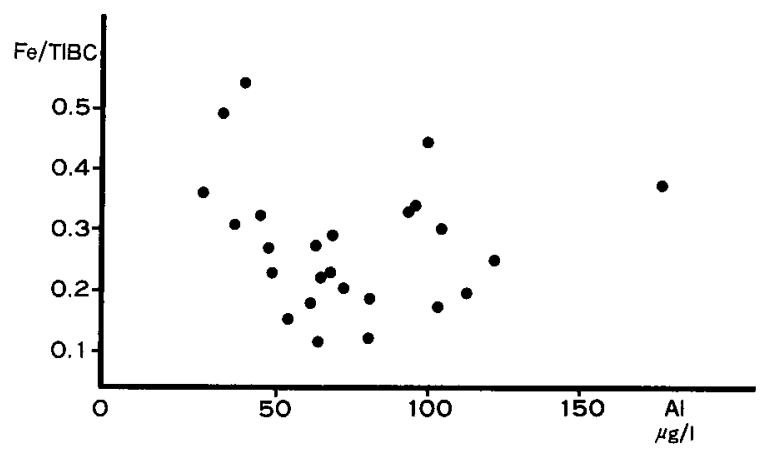

図 9 Relationship between $\mathrm{Fe} / \mathrm{TIBC}$ and $\mathrm{Al}$ in hemodialysis patients

れる.後者については, $\operatorname{Tf}$ の末端への $\mathrm{Fe}$ と $\mathrm{Al}$ の親 和性を直接に比較した報告は調べた限り見当たらない が, Mladenovic ${ }^{10)}$ ，扔よび Yamamura $ら^{14)}$ の報告から Tf のN末端で Fe と $\mathrm{Al}$ の競合がおこると考えられる. 前者の機序については，鉄欠乏が否定しえる状態での比 較が必要であるが，今回の対象例には臨床的に鉄欠乏を 否定しうる $\mathrm{Ft}>50 \mathrm{ng} / \mathrm{m} l$ の症例が少なく, 今後症例が 增えた時点で再検討したい.

一方，実験的には鉄欠乏状態が小腸での $\mathrm{Al}$ 吸収を亢 進させることが指摘されているが15)，今回の測定でも図 4 に示された血清 $\mathrm{Fe}$ 值と $\mathrm{RBC}-\mathrm{Al}$ でも負の相関がみら れ, さらに $\mathrm{Ft}<50 \mathrm{ng} / \mathrm{m} l$ の潜在性もしくは顕性鉄欠乏 の症例での $\mathrm{RBC}-\mathrm{Al}$ 濃度を比較した図 10 に示されたご とく, $\mathrm{Ft}<50 \mathrm{ng} / \mathrm{m} l$ の症例の $\mathrm{RBC}-\mathrm{Al}$ 濃度のほうが有 意に高值であった。また，透析導入時すでに血清 $\mathrm{Al}$ 濃 度が高值を示している ${ }^{6)} こ$ からも明らかなごとく，Al 製剤の使用が厳しく限定されている今日でも維持透析患 者は $\mathrm{Al}$ 污染にさらされている，従って，Al 污染予防の 1つとして維持透析患者では鉄欠乏状態を㛜重に避けね ばならない。なお，今回の検討で $\mathrm{Hb}$ と $\mathrm{RBC}-\mathrm{Al}$ の間

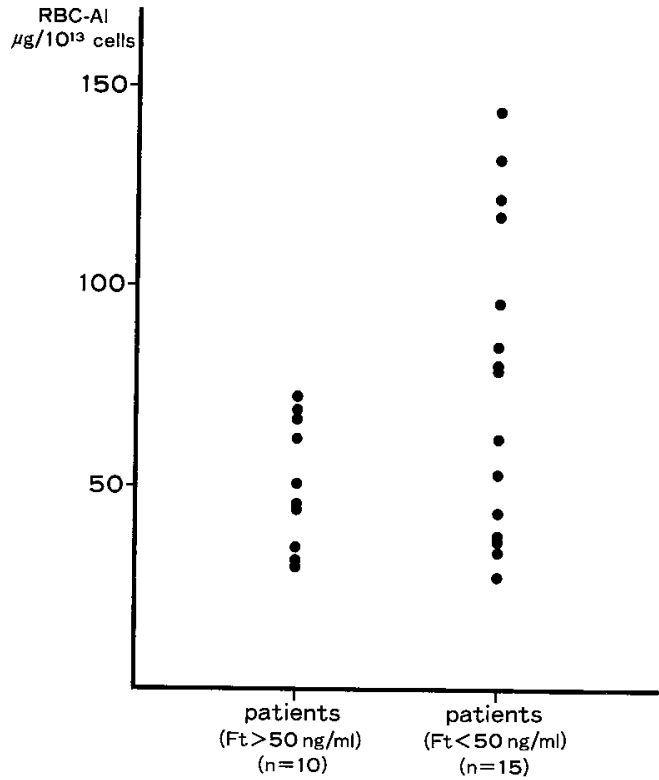

図 $10 \mathrm{RBC}-\mathrm{Al}$ in hemodialysis patients with ferritin $>50 \mathrm{ng} / \mathrm{m} l$ and ferritin $<50 \mathrm{ng} /$ $\mathrm{m} l$

で負の相関を認めなかった(図 3 )ことは，対象例中 $\mathrm{Ft}<$ $50 \mathrm{ng} / \mathrm{m} /$ の潜在的鉄欠乏症例が相当数含まれていたた めと考えられ, $\mathrm{Al}$ による貧血発生を否定するものではな いと解釈される。

\section{結論}

今回, 我々は安定した維持透析患者において, $\mathrm{RBC}-\mathrm{Al}$ 濃度と鉄パラメータの比較検討を行った。

1. $\mathrm{RBC}-\mathrm{Al}$ 濃度は, 健常者では, $31.9 \pm 9.9 \mu \mathrm{g} / 10^{13}$ cells，維持透析患者では， $66.5 \pm 33.6 \mu \mathrm{g} / 10^{13} \mathrm{cells}$ で， 透析患者群で有意に高値を示した。

2. $\mathrm{RBC}-\mathrm{Al}$ 濃度と $\mathrm{Hb}$ の間には，負の相関は認めら れなかった。

3. $\mathrm{RBC}-\mathrm{Al}$ と $\mathrm{Fe} / \mathrm{Tf}$ の間には, $\mathrm{R}=-0.515$ の負の 相関が認められた。

4. $\mathrm{RBC}-\mathrm{Al}$ 濃度と $\mathrm{Fe} / \mathrm{TIBC}$ の間には, $\mathrm{R}=-0.505$ の負の相関が認められた。

5. 以上より，アルミニウム蓄積は，維持透析患者に おいて，鉄代謝障害を示すことが示唆された。

\section{文献}

1) Elliott HL, Dryburgh F, Fell GS, Sabet S, Macdougall $\mathrm{AI}$ : Aluminum toxicity during regular haemodialysis. Br Med J 1 : 1101-1103, 1978

2) Yamada $\mathrm{H}:$ Characterization of serum and red cell ferritin in hematological disorders. Acta 
Haematol Jpn $41: 1334-1338,1978$

3）南 忠義, 古川佳要子, 石田正史, 平尾健谷, 貴宝 院邦彦, 吉田克法, 本宮善恢：維持透析患者におけ るアルミニウム蓄積量の推定. 透析会誌 $21: 1045$ 1049, 1988

4) Kehoe RA, Cholak J, Story RV : A spectrochemical study of the normal ranges of concentration of certain trace metals in biological material. J Nutr 19 : 579-592, 1940

5）菊池正俊, 三浦義昭, 石山 剛, 五十嵐謙一, 下条 文武, 荒川正昭：血液透析患者の貧血と赤血球アル ミニウムについて. 透析会誌 $20: 159-163,1987$

6）梅田 優, 海本浩一, 泉 暢英, 上水流雅人, 西尾 正一, 前川正信：透析患者に扔ける赤血球内アルミ ニウム蓄積について。 人工臟器 $17: 98-101,1988$

7) Van der Voet GB, deWolff FA : Distribution of aluminum between plasma and erythrocytes. Hum Toxicol $4: 643-648,1985$

8) Molitaris BA, Alfrey AC, Smith BJ : Efficacy of intramuscular and intraperitoneal deferoxamine for aluminum chelation. Kidney Int 31 : 986-991, 1987

9）和田秀穂，八幡義人：赤血球膜成分の発現と分化.
医学のあゆみ $155 ： 797-800 ， 1990$

10) Mladenovic $J:$ Aluminum inhibits erythropoiesis in vitro. J Clin Invest $81: 1661-1665,1988$

11）岡島英五郎, 佐々木憲二, 小原壮一, 吉田克法, 金 子佳照, 本宮善恢, 平尾佳彦: へム合成系へのアル ミニウムの影響一赤血球ウロポロフィリノーゲンー 1一合成酵素㧍よびプロトポルフィリンとの関係 一。腎誌 $33: 161-166 ， 1991$

12) Huber CT, Frieden $E$ : The inhibition of ferroxidase by trivalent and other metal ions. J Biol Chem 245 : 3979-3984, 1981

13) Day RS, Eales L, Disler PB : Porphyrias and the kidney. Nephron $28: 261-267,1981$

14) Takaki Yamamura, Sachie Shimo, Toru Tsuda, Kazuo Satake: Difference in the metal-binding properties between the two sites of ovotransferrin. Rep Prog Polymer Physics Jpn 28 : 633-636, 1985

15) Fernandez MJ, Fernandez Sato I, Halls D, Farnandez JL, Brock J, Cannata JB : Iron (Fe) deficiency. A risk for aluminum ( $\mathrm{Al}$ ) gastrointestinal (G-I) hyperabsorption. Kidney Int 37 : 1612, 1990 